DIMENSI, VOL. 8, NO. 2 : 210-239

JULI 2019

ISSN: 2085-9996

\title{
Pengaruh Gaya Kepemimpinan, Beban Kerja, Job Insecurity Terhadap Turnover Intention Karyawan PT. Federal Internasional Finance Cab Batam
}

\section{Effect of Leadership Style, Workload, Job Insecurity on Turnover Intention Employee Of PT. FIF Federal Internasional Finance Batam Branch}

\author{
Siti Solehah ${ }^{1}$, Sri Langgeng Ratnasari ${ }^{2}$ \\ ${ }^{1}$ (Prodi Manajemen, Fakultas Ekonomi, Universitas Riau Kepulauan) \\ ${ }^{2}$ (Prodi Magister Manajemen, Program Pascasarjana, Universitas Riau Kepulauan) \\ ${ }^{1}$ siti.solehah69@yahoo.co.id, ${ }^{2}$ sarisucahyo@yahoo.com
}

\begin{abstract}
Abstrak
Tujuan Penelitian ini untuk mengetahui pengaruh gaya kepemimpinan, beban kerja, dan job insecurity, terhadap Turnover intention pada PT. Federal Internasional Finance Cabang Batam. Jenis Penelitian ini adalah deskriptif kuantitatif dengan teknik pengumpulan data menggunakan kuesioner. Populasi penelitian ini 123 orang dengan sampel 55 orang karyawan. Teknik samplingnya meggunakan rumus Slovin. Hasil Pengujian hipotesis untuk variabel Gaya Kepemimpinan (X1) menunjukan hasil t hitung 1,079 < t tabel 2,007 dan signifikan sebesar 0,286 $>0,05$ sehingga keputusan yang diambil adalah $\mathrm{H}_{\mathrm{o}}$ diterima dan $\mathrm{H}_{\mathrm{a}}$ ditolak. Hal ini berarti Gaya Kepemimpinan berpengaruh tidak signifikan terhadap Turnover Intention. Pengujian hipotesis untuk variabel Beban Kerja (X2) menunjukkan nilai $\mathrm{t}$ hitung 2,912 > t tabel 2,007 dan nilai signifikan 0,005 $<0,05$ sehingga keputusan yang diambil adalah $\mathrm{H}_{\mathrm{o}}$ ditolak dan $\mathrm{H}_{\mathrm{a}}$ diterima. Hal ini berarti bahwa Beban Kerja berpengaruh secara signifikan terhadap Turnover Intention. Pengujian hipotesis variabel Job Insecurity (X3) nilai t hitung 2,900 > t tabel 2,007 dan nilai signifikan $0,005<0,05$ sehingga keputusan yang diambil adalah $\mathrm{H}_{\mathrm{o}}$ ditolak dan $\mathrm{H}_{\mathrm{a}}$ diterima. Hal ini berarti bahwa Job Insecurity berpengaruh secara signifikan terhadap Turnover Intention. Hasil uji $\mathrm{F}$ memperlihatkan nilai $\mathrm{F}$ sebesar 7,836 (F hitung) > 2,78 (F tabel) dan nilai signifikansi sebesar $0,000<0,05$ sehingga keputusan yang diambil adalah $\mathrm{H}_{\mathrm{o}}$ ditolak dan $\mathrm{H}_{\mathrm{a}}$ diterima. Hasil ini menunjukkan bahwa variabel Gaya Kepemimpinan (X1), Beban Kerja (X2), dan Job Insecurity (X3) secara simultan mempunyai pengaruh signifikan terhadap variabel Turnover Intention (Y).
\end{abstract}

Kata Kunci: Gaya Kepemimpinan, Beban Kerja, Job Insecurity, Trunover Intention

\begin{abstract}
The purpose of this study was to determine the effect of leadership style, workload, and job insecurity, on Turnover intention at PT. Federal International Finance Batam Branch. This type of research is descriptive quantitative with data collection techniques using a questionnaire. The population of this study was 123 people with a sample of 55 employees. The sampling technique uses the Slovin formula. The results of testing the hypothesis for the Leadership Style variable (X1) shows the results of t count $1.079<t$ table 2.007 and significant at 0.286> 0.05 so that the decisions taken are Ho accepted and Ha rejected. This means that the Leadership Style has no significant effect on Turnover Intention. Hypothesis testing for Workload variable (X2) shows the value of t count 2.912> t table 2.007 and significant value $0.005<0.05$ so that the decision taken is Ho rejected and Ha accepted. This means that Workload has a significant effect on Turnover Intention. Variable hypothesis testing Job Insecurity (X3) value of $t$ count 2,900>t table 2,007 and significant value 0,005 0,05 so that the decision taken is Ho rejected and Ha accepted. This means that Job Insecurity has a significant effect on Turnover Intention. The results of the $F$ test show an $F$ value of 7.836 ( F count $)>2.78$ (F table $)$ and a significance value of
\end{abstract}


$0,000<0.05$ so that the decision taken is Ho rejected and Ha accepted. These results indicate that the Leadership Style (X1), Workload (X2), and Job Insecurity (X3) variables simultaneously have a significant effect on Turnover Intention $(Y)$ variables.

Keywords: Leadership Style, Workload, Job Insecurity, Trunover Intention

\section{PENDAHULUAN}

Gaya kepemimpinan merupakan norma perilaku yang digunakan oleh seseorang pada saat orang tersebut mencoba mempengaruhi perilaku orang lain. Gaya kepemimpinan cocok apabila tujuan perusahaan telah dikomunikasikan dan bawahan telah menerimanya. Seorang pemimpin harus menerapkan gaya kepemimpinan untuk mengelola bawahannya, karena seorang pemimpin akan sangat mempengaruhi keberhasilan organisasi dalam mencapai tujuannya. Pemimpin mendengar ide-ide dari para bawahan sebelum mengambil keputusan. Gaya kepemimpinan yang tepat akan menimbulkan motivasi seseorang untuk berprestasi sukses tidaknya karyawan dalam prestasi kerja dapat di pengaruhi oleh gaya kepemimpinan atasanya karena gaya kepemimpinan mempunyai pengaruh yang signifikan terhadap kinerja karyarwan. Gaya kepemimpinan akan menunjukan secara langsung maupun tidak langsung, tentang keyakinan seorang pimpinan terhadap kemampuan bawahannya, artinya gaya kepemimpinan adalah perilaku dan strategi, sebagai hasil kombinasi dan falsafah,keterampilan, sifat, sikap yang sering diterapkan seorang pemimpin ketika ia mencoba mempengaruhi kinerja bawahanya. Hal ini juga terjadi di PT. Federal Internasional Finance Cab batam.

Seperti halnya di sektor lain, pekerjaan di industri jasa merasakan dampak negatif dari kelebihan beban kerja pada kesehatan psikologi dan fisik karyawan. Karyawan harus memenuhi tuntunan organisasi mengenai kuantitas pekerjaan yang harus diselesaikan di bawah tekanan waktu, tuntutan emosional yang terkait dengan interaksi mereka dengan konsumen atau klien, dan sedikitnya fleksibilitas pengambilan keputusan yang tersedia bagi karyawan yang tersedia bagi karyawan dalam tugas harian yang lama kelamaan karyawan tersebut berkeinginan untuk mengundurkan diri karna beban kerja yang terlalu besar. Menurut Hart dan Staveland dalam Tarwaka (2015), bahwa beban kerja merupakan sesuatu yang 
muncul dari interaksi antara tuntutan tugas-tugas, lingkungan kerja dimana digunakan sebagai tempat kerja, keterampilan, perilaku dan presepsi dari pekerja. Beban kerja kadang-kadang juga dapat didefinisikan secara operasional pada berbagai faktor seperti tuntutan tugas atau upaya-upaya yang dilakukan untuk pekerjaan. Job insecurity atau ketidakamanan kerja sangat sering dirasakan karyawan di dalam organisasi, terlebih lagi ketika fasilitas di dalam organisasi tersebut kurang memadai, sehingga mengakibatkan karyawan tidak nyaman bekerja dan akan mempertimbangkan tetap bertahan atau tidak di dalam organisasi tersebut.

Menurut Suciati dkk., (2015) job insecurity adalah ketidakberdayaan untuk mempertahankan kesinambungan yang diinginkan dalam kondisi kerja yang terancam. job insecurity dikonseptualisasikan sebagai ketidakpastian dan kurangnya kontrol dari kelanjutan masa depan pekerjaan karyawan (Kekesi dan Collins, 2014). Karyawan mengalami rasa tidak aman (job insecurity) yang makin meningkat karena ketidakstabilan terhadap status kepegawaian mereka dan tingkat pendapatan yang makin tidak bisa diramalkan, akibatnya intensi pindah kerja (turnover) cenderung meningkat, serta faktor usia, lama kerja, juga berperan penting dalam terjadinya turnover intention (Hanafiah, 2014).

Turnover intention dapat menelan biaya yang tinggi. Menurut Waspodo dkk (2013), tingginya tingkat Turnover intention telah mejadi masalah bagi banyak perusahaan, dimana dampak negatif yang dirasakan adala sulitnya mendapatkan kualitas dan kemampuan yang sesuai dengan kualifikasi yang telah ditetapkan oleh perusahaan serta dibutuhkan waktu dan biaya dalam merekrut karyawan baru. Oleh karena itu, organisasi perlu menguranginya sampai pada tingkat-tingkat yang dapat diterima. Namun demikian, mempertahankan tingkat perputaran sebesar nol adalah tidak realistis dan bahkan tidak dikehendaki. Berdasarkan pada hasil penelitian yang dilakukan oleh beberapa peneliti, penelitian ini akan melakukan pengujian kembali terhadap beberapa faktor yang diprediksi berpengaruh terhadap keinginan berpindah karyawan.

Faktor-faktor tersebut adalah gaya kepemimpinan,beben kerja dan job insecurity. Setiap perusahaan pasti pernah mengalami turnover intention karyawannya, begitu pula yang dialami oleh PT. Federal International Finance member of Astra Cabang Batam. Perusahaan ini merupakan perusahaan yang bergerak pada bidang jasa khususnya jasa pembiayaan motor 
baru HONDA, motor bekas, mobil bekas serta pembiayaan pada alat-alat rumah tangga. PT. FIF GROUP Cabang Batam memiliki 6 kios yang ada di Batam yang memiliki 213 karyawan. Adapun presentase (\%) turnover karyawan PT. FIF Group member of astra cabang Batam Tahun 2015-2017 dapat dilihat pada Tabel 1

\section{Tabel 1}

\begin{tabular}{llll}
\multicolumn{4}{c}{ Data Rata-rata Turnover Karyawan PT. FIF GROUP } \\
Tahun & $\mathbf{2 0 1 5 - 2 0 1 7}$ & \\
\hline Tahun & $\mathbf{2 0 1 5}$ & $\mathbf{2 0 1 6}$ & $\mathbf{2 0 1 7}$ \\
\hline Karyawan awal & 507 & 410 & 306 \\
Karyawan akhir & 410 & 306 & 213 \\
Diterima & 57 & 110 & 98 \\
Keluar & 97 & 104 & 93 \\
$\%$ & $\mathbf{8 , 7 2 \%}$ & $\mathbf{1 1 , 5 \%}$ & $\mathbf{1 0 , 7 \%}$
\end{tabular}

Sumber: Bagian HRD PT. FIF GROUP Cab Batam, 2018

Tabel 1 dapat menggambarkan adanya turnover yang terjadi pada PT. FIF GROUP Cabang Batam dari tahun 2015 sampai januari 2017 yang mengalami peningkatan setiap tahunnya. Besarnya turnover pada tahun 2016 hampir melampaui besarnya turnover pada tahun 2015 yaitu sebesar $11,5 \%$.

Walaupun besarnya turnover pertahunnya belum mencapai setengah atau 50\%, namun cukup menarik perhatian pada PT. FIF Group Cabang Batam. Hal ini dikarenakan PT. FIF Group Cabang Batam merupakan perusahaan kredit yang sudah dipercaya masyarakat dalam pemberian kredit dan tergolong baik sehingga diharapkan mampu mengambil agar turnover menjadi lebih rendah pada masa yang akan datang. Turnover pada PT. FIF Group Cabang Batam menunjukkan besarnya keinginan untuk pindah pekerjaan. Makin meningkatnya angka turnover menunjukkan bahwa karyawan PT. FIF Group Cabang Batam merasa tidak betah dan bahkan tidak puas dalam bekerja.

Ketidakpuasan dalam bekerja menunjukkan pula bahwa karyawan merasa kecewa pada perusahaan, sehingga mereka memperlihatkan perilaku kerja yang negatif seperti: terlambat datang kerja, tidak masuk kerja, menunda pekerjaan, bahkan keputusan untuk keluar dari perusahaan, namun demikian, jika karyawan merasa puas terhadap pekerjaan yang mereka lakukan, maka pekerjaan tersebut dapat memberikan keuntungan bagi perusahaan serta dapat 
tercapainya target yang ditentukan oleh perusahaan. Karyawan - karyawan merasa beban kerja mereka terlalu tinggi karena harus mengerjakan pekerjaan di luar job description mereka, ditambah dengan kurangnya perhatian dari atasan terhadap situasi dan kondisi yang meperlambat pekerjaan mereka seperti kurangnya perhatian terhadap kondisi peralatan dan lingkungan kerja. Selain itu hubungan kerjasama antar karyawan kurang, menyebabkan menumpuknya pekerjaan yang harus dilakukan.

Masalah lain yang datang dari karyawan-karyawan yang ada pada section collection dan office boy. Dimana para karyawan merasa kurang setuju dengan sikap dari atasan yang memberikan perintah dengan cara kasar dan tidak memperhatikan situasi serta kondisi yang sedang dialami oleh karyawan. Atas dasar hal-hal tersebut, maka peneliti menganggap masalah tersebut cukup menarik dan akan dilakukan penelitian didalam masing-masing departemen. Adapun judul penelitian ini adalah Pengaruh gaya kepemimpinan, Beban kerja dan job insecurity terhadap turnover intention pada PT. Federal Internasional Finance Cab Batam.

\section{METODE PENELITIAN}

Penelitian ini menggunakan pendekatan kuantitatif, dengan metode pengumpulan data kuisioner, Populasi dari penelitian ini adalah seluruh karyawan PT. FIF GROUP Cabang Batam yang berjumlah 123 orang. Pengambilan sampel berdasarkan rumus Slovin adalah 55,15 yang dibulatkan menjadi 55 sampel dengan menggunakan teknik sampling random.

\section{Teknik Analisis Data}

\section{Uji Instrumen}

Instrumen penelitian digunakan untuk mengukur nilai variabel yang diteliti. Instrumen - instrumen penelitian sudah ada yang dilakukan, tetapi masih ada yang harus dibuat peneliti sendiri. Oleh instrumen penelitian akan digunakan untuk melakukan pengukuran dengan tujuan menghasilkan data kuantitatif yang akurat, maka setiap instrumen harus mempunyai skala. Metode kuantitatif ini menggunakan skala Likert.

Menurut Sugiyono (2018) skala Likert adalah skala yang digunakan untuk mengukur sikap, pendapat responden tentang fenomena sosial. Skala Likert maka variabel akan diukur dan dijabarkan menjadi indikator variabel, kemudian indikator tersebut dijadikan sebagai titik 
tolak untuk menyusun item - item instrumen yang dapat berupa pertanyaan atau pernyataan baik bersifat favorable (positif) ataupun unfavorable (negatife). Dimana dengan skala ini akan memberikan kemudahan kepada responden dalam menjawab serta memberikan kemudahan untuk dapat mengolah data. Adapun alternatif jawaban dengan menggunakan skala Likert, yaitu sebagai berikut dapat ditunjukan pada Tabel 3.2. Dapat dilihat jawaban dan bobot skor untuk item-item instrumen pada pertanyaan dalam kuesioner:

\section{Uji Validitas}

Pada penelitian, untuk memperoleh data yang baik, maka kuesioner yang dijadikan instrumen pengumpulan data harus diuji terlebih dahulu validitas dan reliabilitasnya. Instrumen yang valid berarti alat ukur yang digunakan untuk mengukur data itu valid. Valid berarti instrumen tersebut dapat digunakan untuk mengukur apa yang seharusnya diukur.Uji validitas digunakan untuk mengukur sah atau valid tidaknya suatu kuesioner. Suatu kuesioner dikatakan valid jika pernyataan pada kuesioner mampu untuk mengungkapkan sesuatu yang akan diukur oleh kuesioner (Sugiyono, 2018).

Pada penelitian ini alat ukur yang digunakan adalah kuesioner. Untuk mencari validitas, harus mengkorelasikan skor dari setiap pertanyaan dengan skor total seluruh pertanyaan. Jika memiliki koefisien korelasi lebih besar dari 0,3 maka dinyatakan valid tetapi jika koefisien korelasinya dibawah 0,3 maka dinyatakan tidak valid. Dalam mencari nilai korelasi, maka penulis menggunakan rumus Pearson Product Moment, dengan rumus sebagai berikut:

$$
\mathrm{r}_{\mathrm{xy}}=\frac{n \cdot\left(\sum x\right)\left(\sum y\right)}{\sqrt{\left(n \cdot \sum x^{2}-\left(\sum x\right)^{2}\right)\left(n \cdot \sum y^{2}-\left(\sum y\right)^{2}\right)}}
$$

Keterangan:

$$
\begin{array}{ll}
\mathrm{r}_{\mathrm{xy}} & =\text { Koefisien korelasi } \\
\mathrm{X} & =\text { Skor item instrument } \\
\mathrm{Y} & =\text { Skor total item instrumen dalam variabel (kinerja pegawai ) } \\
\mathrm{n} & =\text { Jumlah responden }
\end{array}
$$

Untuk mencari nilai validitas di sebuah item kita mengkorelasikan skor item dengan total item-item tersebut. Jika ada item yang tidak memenuhi syarat, maka item tersebut tidak akan 
diteliti lebih lanjut. Syarat tersebut menurut Sugiyono (2018) yang harus dipenuhi yaitu harus memenuhi kriteria sebagai berikut:

a. Jika $r \geq 0,03$ maka item-item tersebut dinyatakan valid.

b. Jika $r \leq 0,03$ maka item-item tersebut dinyatakan tidak valid.

\section{Uji Reliabilitas}

Sugiyono, (2018) uji reliabelitas adalah alat untuk mengukur suatu kuesioner yang merupakan indikator dari variabel dan konstruk, butir pertanyaan dikatakan realible atau handal apabila jawaban seseorang terhadap pertanyaan adalah konsisten dan stabil dari waktu ke waktu.

Dalam penelitian ini, teknik uji reliabilitas yang digunakan para peneliti adalah dengan melihat dan membandingkan antara chronbach's Alpha pada hasil SPSS V. 25. koefisien alpha cronbach merupakan statistik uji yang paling umum digunakan para peneliti untuk menguji reliabilitas suatu instrumen penelitian. Dilihat menurut statistik alpha chronbach, suatu instrumen penelitian diindikasikan memiliki reliabilitas yang memadai jika koefisien alpha cronbach lebih besar atau sama dengan 0,60. Uji alpha cronbach dirumuskan sebagai berikut:

keterangan:

$$
\alpha=\frac{k}{k-1}\left(1-\frac{\sum_{\sigma} 2 x i}{\sigma^{2} x}\right)
$$

$$
\begin{array}{ll}
\alpha & =\text { cronbach's coefficient alpha } \\
\mathrm{k} & =\text { jumlah item pertanyaan yang diuji } \\
\sum_{\sigma} 2 x i & =\text { total dari varian masing-masing pecahan } \\
\sigma_{\mathrm{x}}^{2} & =\text { varian dari total skor }
\end{array}
$$

\section{Uji Normalitas}

Menurut sunyoto (2014) uji asumsi ini dilakukan untuk menguji data variabel bebas (X) dan data variabel terikat (Y) pada persamaan regresi yang dihasilkan, apakah berdistribusi normal atau berdistribusi tidak normal. Persamaan regresi dikatakan baik jika mempunyai data variabel bebas dan data variabel terikat yang berdistribusi mendekati normal atau normal. Untuk menguji normalitas dapat dilakukan dengan menggunakan SPSS dengan melihat sig pada tabel test of normality kemudian kolom kolmogorov - smirnov ${ }^{a}$ dan membandingkan dengan alpha yang digunakan. Jika sig $\geq$ alpha maka data berdistribusi normal, jika sig $\leq$ 
alpha maka data berdistribusi tidak normal. Selain itu, normal atau tidaknya suatu data dilihat dari penyebaran data (titik) pada sumbu diagonal grafik, jika datanya menyebar di sekitar garis diagonal, maka regresi memenuhi asumsi normalitas dan sebaliknya.

\section{Uji Heteroskedastistas}

Uji heteroskedastisitas bertujuan menguji apakah dalam model regresi terjadi ketidaksamaan variance dari residual satu pengamatan ke pengamatan yang lain. Jika variance dari residual satu pengamatan ke pengamatan yang lain tetap, maka disebut homoskedastisitas dan jika berbeda disebut heteroskedastisitas. Model regresi yang baik adalah yang homoskedastisitas atau tidak terjadi heteroskedastisitas. Kebanyakan data crossection mengandung situasi heteroskedastisitas karena data ini menghimpun data yang mewakili berbagai ukuran (kecil, sedang, dan besar) Ghozali (2013).

Deteksi ada atau tidaknya heteroskedastisitas dapat dilakukan dengan melihat ada tidaknya pola tertentu pada grafik scatterplot antara SRESID dan ZPRED dimana sumbu Y adalah $\mathrm{Y}$ yang telah diprediksi dan sumbu $\mathrm{X}$ adalah residual (Y prediksi-Y sesungguhnya) yang telah di-studentized. Uji white yang pada prinsipnya meregres residual yang dikuadratkan dengan variabel bebas pada model. Kriteria uji white adalah: $\mathrm{P}$ rob Obs*R square $>0,05$, maka tidak ada heteroskedastisitas. Dasar analisis adalah sebagai berikut:

1) Jika ada pola tertentu, seperti titik-titik yang ada membentuk pola tertentu yang teratur (bergelombang, melebar kemudian menyempit), maka mengindikasikan telah terjadi heteroskedastisitas.

2) Jika tidak ada pola yang jelas, serta titik-titik menyebar di atas dan di bawah angka nol pada sumbu Y, maka tidak

\section{Uji Multikolinearitas}

Multikolinieritas merupakan suatu situasi dimana beberapa atau semua variabel independen saling berkorelasi tinggi. Jika terdapat korelasi yang sempurna diantara sesama variabel independen sehingga nilai koefisien korelasi diantara sesama variabel independen ini sama dengan satu, maka konsekuensinya adalah:

1. Koefisien-koefisien regresi menjadi tidak stabil

2. Nilai standar error setiap koefisien regresi mejadi tidak terhingga 
Dengan demikian berarti semakin besar korelasi diantara sesama variabel independen, maka koefisien-koefisien regresi semakin besar kesalahannya dan standar errornya semakin besar pula. Cara yang digunakan untuk mendeteksi ada tidaknya multikolinieritas adalah dengan menggunakan Variance Inflation Factors (VIF).

$$
V I F=\frac{1}{1-R i^{2}}
$$

$\mathrm{Ri}^{2}$ adalah koefisien determinasi yang diperoleh dengan meregresikan salah satu variabel bebas X1 terhadap variabel bebas lainnya. Jika nilai VIF di atas atau lebih besar dari 10 maka diantara veriabel independen terdapat gejala multikolinieritas.

\section{Rancangan Analisis dan Uji Hipotesis}

\section{Rancangan Analisis}

Dalam menganalisis dan melakukan uji hipotesis, perlu adanya suatu rancangan dalam pengolahan data dari instrumen yang digunakan. Berikut merupakan uraian dari langkah-langkah dalam rancangan analisis dan uji hipotesis.

\section{Rancangan Pengujian Hipotesis}

Hipotesis yang akan diuji dan dibuktikan dalam penelitian ini berkaitan dengan ada atau tidaknya pengaruh variabel bebas yang perlu diuji kebenarannya dalam suatu penelitian. Sugiyono (2016) menyatakan bahwa yang dimaksud dengan hipotesis adalah jawaban sementara terhadap rumusan masalah penelitian, dimana rumusan masalah penelitian telah dinyatakan bentuk kalimat pertanyaan. Hal ini sementara, karena jawaban yang diberikan baru didasarkan pada teori yang relevan, belum didasarkan pada fakta-fakta empiris yang diperoleh melalui pengumpulan data. Rancangan pengujian hipotesis digunakan untuk mengetahui korelasi dari kedua variabel yang diteliti. Tahap-tahap dalam rancangan pengujian hipotesis ini dimulai dengan penetapan hipotesis nol $(\mathrm{Ho})$ dan hipotesis alternatif $(\mathrm{Ha})$, pemilihan tes statistik, perhitungan nilai statistik dan penetapan tingkat signifikan. 


\section{Regresi Linier Berganda}

Analisis regresi linier berganda merupakan suatu teknik statistika yang digunakan untuk mencari persamaan regresi yang bermanfaat untuk meramal nilai variabel dependen berdasarkan nilai-nilai variabel independen dan mencari kemungkinan kesalahan dan menganalisa hubungan antara satu variabel dependen dengan dua atau lebih variabel independen baik secara simultan maupun parsial.

Analisis regresi linier berganda digunakan untuk menguji apakah variabel independen memiliki pengaruh terhadap variabel dependen secara simultan maupun parsial.

$$
Y=b_{0}+b_{1} X_{1}+b_{2} X_{2}+b_{3} X_{3}+e
$$

$$
\begin{array}{cl}
\text { Keterangan : } & \\
\text { Y } & =\text { Turnover Intention } \\
\text { bo } & =\text { Bilangan Konstanta } \\
\text { b1,b2 } & =\text { Koefisien regresi } \\
\mathrm{X} 1 & =\text { Gaya Kepemimpinan } \\
\mathrm{X} 2 & =\text { Beban Kerja } \\
\mathrm{X} 3 & =\text { Job Insecurity } \\
\mathrm{e} & =\text { Epsilon (pengaruh faktor lain) }
\end{array}
$$

\section{Uji Korelasi}

Untuk menghitung keeratan hubungan atau koefisien korelasi antara variabel $\mathrm{X}$ dengan variabel $\mathrm{Y}$, dilakukan dengan cara menggunakan perhitungan analisis koefisien korelasi spearman's rho. Rumusnya yaitu:

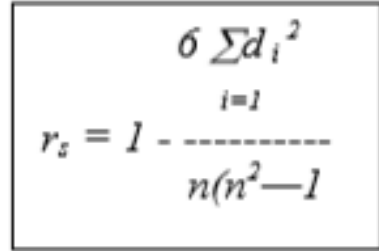

Keterangan :

$\mathrm{r}_{\mathrm{s}}=$ Koefisien korelasi Rank Spearman yang menunjukkan keeratan hubungan antara unsur-unsur variabel $\mathrm{X}$ dan variabel $\mathrm{Y}$. 
$\mathrm{d}_{\mathrm{i}}=$ Selisih mutlak antara rangking data variabel $\mathrm{X}$ dan variabel $\mathrm{Y}$ (X1-Y1).

$\mathrm{n}=$ Banyaknya responden atau sampel yang diteliti.

Untuk dapat memberikan penafsiran terhadap koefisien korelasi yang ditemukan besar atau kecil, maka dapat disimpulkan pada ketentuan-ketentuan untuk memberikan interpretasi koefisien korelasi diantaranya yang dapat dilihat dalam Tabel 2 di bawah ini.

Tabel 2

Pedoman Untuk Memberikan Interprestasi Terhadap Koefisien Korelasi

\begin{tabular}{cc}
\hline Intrerval Koefisien & Tingkat Hubungan \\
\hline $0,00-0,199$ & Sangat rendah \\
$0,20-0,399$ & Rendah \\
$0,40-0,599$ & Sedang \\
$0,60-0,799$ & Kuat \\
$0,80-1,000$ & Sangat Kuat \\
\hline
\end{tabular}

Sumber: Sugiyono, 2016

\section{Uji Koefisien Determinasi $\left(\mathbf{R}^{2}\right)$}

Analisis korelasi dapat dilanjutkan dengan menghitung koefisien determinasi ini berfungsi untuk mengetahui persentase besarnya pengaruh variabel $\mathrm{X}$ terhadap variabel $\mathrm{Y}$. Menurut Gujarati (2013) untuk melihat besar pengaruh dari setiap variabel bebas terhadap variabel terikat secara parsial, dilakukan perhitungan dengan menggunakan rumus berikut:

$$
\mathrm{Kd}=\text { Zero Order } \times \beta \times 100 \%
$$

Keterangan:

$$
\begin{array}{ll}
\text { Kd } & =\text { Koefisien determinasi } \\
\text { Zero Order } & =\text { Koefisien korelasi } \\
\beta & =\text { Koefisien } \beta \text { eta }
\end{array}
$$


Untuk melihat seberapa besar tingkat pengaruh variabel independen terhadap variabel dependen secara simultan digunakan koefisien determinasi (KD) menurut Sujarweni (2012) rumus determinasi sebagai berikut:

$$
\mathrm{Kd}=\mathrm{R}^{2} \times 100 \%
$$

Keterangan :

Kd $=$ Koefisien Determinasi

$\mathrm{r}_{2} \quad=$ Koefisien Korelasi

Koefisien Determinasi (KD) merupakan kuadrat dari koefisien korelasi sebagai ukuran untuk mengetahui kemampuan dari masing-masing variabel yang digunakan dalam penelitian. Nilai KD yang kecil berarti kemampuan variabel-variabel independen dalam menjelaskan variabel dependen amat terbatas. Analisis ini digunakan untuk mengetahui seberapa besar pengaruh variabel-variabel independen yaitu Gaya Kepemimpinan, Beban Kerja, Job Insecuurity Terhadap variabel dependen yaitu Turnover Intention dinyatakan dalam persentase.

\section{Pengujian Hipotesis Secara Parsial (Uji $t$ )}

Uji statistic $t$ disebut juga sebagai uji signifikan individual dimana uji ini menunjukkan seberapa jauh pengaruh variabel independen secara parsial terhadap variabel dependen. Bentuk pengujiannya adalah:

$$
\text { Ho: } r=0 \text { atau } \mathrm{Ha}: r \neq 0
$$

\section{Keterangan :}

Ho $=$ Format hipotesis awal (Hipotesis nol)

$\mathrm{Ha}=$ Format hipotesis alternatif

1. Penetapan hipotesis statistic

a. Variabel Gaya Kepemimpinan (X1)

Ho : $\beta 1=0$, artinya Gaya Kepemimpinan tidak berpengaruh terhadap

Turnover Inttention 
Ho : $\beta 1 \neq 0$, artinya Gaya Kepemimpinan berpengaruh terhadap Turnover

\section{Inttention}

b. Beban Kerja (X2)

Ho : $\beta 1=0$, artinya Beban Kerja tidak berpengaruh terhadap Turnover Inttention

Ho : $\beta 1 \neq 0$, artinya Beban Kerja berpengaruh terhadap Turnover Inttention

c. Job Insecurity (X2)

Ho : $\beta 1=0$, artinya Job Insecurity tidak berpengaruh terhadap Turnover Inttention

Ho : $\beta 1=0$, artinya Job Insecurity berpengaruh terhadap Turnover Inttention

2. Pengujian nilai tes statistik

Pada penelitian ini melakukan pengujian hipotesis dengan menggunakan product moment. Rumus untuk mengukur koefisien product moment menurut Sugiyono (2016) sebagai berikut:

$$
r_{x y}=\frac{n \sum X Y-\left(\sum X\right)\left(\sum Y\right)}{\sqrt{\left(n \sum X^{2}-\left(\sum X\right)^{2}\right)\left(n \sum Y^{2}-\left(\sum Y\right)^{2}\right)}}
$$

Keterangan:

$\mathrm{r}=$ Koefisien korelasi pearson (product moment)

$\Sigma x y=$ Jumlah perkalian variabel $\mathrm{x}$ dan $\mathrm{y}$

$\Sigma \mathrm{x}=$ Jumlah nilai variabel $\mathrm{x}$

$\Sigma y=$ Jumlah nilai variabel y

$\Sigma \mathrm{x}^{2}=$ Jumlah pangkat dua nilai variabel $\mathrm{x}$

$\Sigma \mathrm{y}^{2}=$ Jumlah pangkat dua nilai variabel y

$\mathrm{n}=$ Banyaknya sampel

Pengolahan data akan dilakukan dengan menggunakan alat bantu aplikasi software IBM SPSS agar pegukuran data yang dihasilkan lebih akurat. Selanjutnya untuk mencari nilai $t$ hitung menurut Sugiyono (2016) maka pengujian tingkat signifikannya adalah dengan menggunakan rumus:

$$
t=\frac{r \sqrt{n}-2}{\sqrt{1}-r^{2}}
$$


Keterangan :

$\mathrm{r}=$ Korelasi

$\mathrm{n}=$ Banyaknya sampel

$\mathrm{t}=$ Tingkat signifikan $\mathrm{t}_{\text {Hitung }}$ yang selanjutnya dibandingkan dengan $\mathrm{t}_{\text {Tabel }}$

Kemudian menentukan model keputusan dengan menggunakan statistik uji $t$, dengan melihat asumsi sebagai berikut:

a. Interval keyakinan $\alpha=0,05$

b. Derajat kebebasan $=n-2=n-k-1$ dimana $k$ adalah jumlah variabel

c. Dilihat hasil $t_{\text {tabel }}$

Hasil hipotesis $t_{\text {Hitung }}$ dibandingkan dengan $t_{\text {tabel }}$ dengan ketentuan sebagai berikut:

a. Jika $t_{\text {Hitung }}>t_{\text {tabel }}$ pada $\alpha=5 \%$ maka H0 ditolak dan Ha diterima (berpengaruh)

b. Jika $t_{\text {Hitung }}<t_{\text {tabel }}$ pada $\alpha=5 \%$ maka H0 diterima dan Ha ditolak (tidak berpengaruh)

\section{Pengujian Hipotesis Secara Simultan (Uji $f$ )}

Pada pengujian simultan akan diuji pengaruh ketiga variabel independen secara bersama-sama terhadap variabel dependen. Uji statistik yang digunakan pada pengujian simultan adalah Uji F atau yang biasa disebut dengan Analysis of varian (ANOVA). Pengujian hipotesis menurut Sugiyono (2016) dapat digukan rumus signifikan korelasi ganda sebagai berikut:

$$
F h=\frac{\mathrm{R} 2 / \mathrm{k}}{(1-R 2) /(n-k-1)}
$$

Keterangan :

$\mathrm{R}=$ Koefisien Korelasi ganda

$\mathrm{K}=$ Jumlah Variabel independen

$\mathrm{N}=$ Jumlah anggota sampel

$\mathrm{Dk}=(\mathrm{n}-\mathrm{k}-1)$ derajat kebebasan

Pengujian membandingkan fhitung dengan ftabel dengan ketentuan sebagai berikut:

a. Jika $\mathrm{f}_{\text {Hitung }}>\mathrm{f}_{\text {Tabel }}$ maka Ho ditolak dan Ha diterima (berpengaruh)

b. Jika $\mathrm{f}_{\text {Hitung }}<\mathrm{f}_{\text {Tabel }}$ maka Ho ditolak dan Ha diterima (tidak berpengaruh)

Penetapan hipotesis nol (Ho) dan hipotesis alternative $(\mathrm{H} \alpha)$ sebagai berikut:

Ho $: \rho=0$ artinya Gaya Kepemimpinan, Beban Kerja, Job Insecurity, berpengaruh signifikan terhadap Turnover Intention. 
$\mathrm{H} \alpha: \rho \neq 0 \quad$ artinya Gaya Kepemimpinan, Beban Kerja, Job Insecurity, berpengaruh tidak signifikan terhadap Turnover Intention.

\section{PEMBAHASAN}

\section{Pengujian Data}

\section{Karakteristik Responden}

Untuk mengetahui pengaruh Gaya Kepemimpinan, Beban Kerja, Job Insecurity, Terhadap Turnover Intention Pada PT. FIF GROUP Cabang Batam. Terdapat 55 karyawan yang dijadikan responden, gambaran umum karasteristik responden, dalam table berikut diuraikan presentase responden tersebut yang mencakup jenis kelamin, usia, lama bekerja dan tingkat pendidikan. Data tersebut kemudian diproses dengan mengunakan program Statistcal Product and Service Solution (SPSS) versi 25. Adapun hasil karekteristik responden yang diolah dari hasil penyebaran kuisioner adalah sebagai berikut.

\section{Responden Menurut Jenis Kelamin}

Depenelitian responden berdasarkan klasifikasi jenis kelamin dalam penelitian ini dapat dilihat pada Tabel 3 sebagai berikut:

\section{Tabel 3}

Data Responden Berdasarkan Jenis Kelamin

\begin{tabular}{|l|l|c|c|c|c|}
\hline \multicolumn{2}{|c|}{} & Frequency & Percent & $\begin{array}{l}\text { Valid } \\
\text { Percent }\end{array}$ & $\begin{array}{l}\text { Cumulative } \\
\text { Percent }\end{array}$ \\
\hline \multirow{3}{*}{ Valid } & LAKI-LAKI & 35 & 63.6 & 63.6 & 63.6 \\
\cline { 2 - 6 } & PEREMPUAN & 20 & 36.4 & 36.4 & 100.0 \\
\cline { 2 - 6 } & Total & 55 & 100.0 & 100.0 & \\
\hline
\end{tabular}

Sumber: Hasil pengolahan data SPSS V.25, 2018

Berdasarkan Tabel 3 atas dapat digambarkan bahwa jumlah responden sebanyak 55, dengan jumlah responden laki-laki sebanyak 35 orang dan responden perempuan sebanyak 20 orang atau sebesar $63.6 \%$ laki-laki dan $36.40 \%$ perempuan dari seluruh jumlah responden. Dengan demikian dapat disimpulkan responden berjenis kelamin laki-laki lebih banyak dari pada responden perempuan. 


\section{Responden Menurut Usia}

Depenelitian responden berdasarkan klasifikasi usia dalam penelitian ini dapat dilihat pada Tabel 4 sebagai berikut:

\section{Tabel 4}

Data Responden Berdasarkan Usia

\begin{tabular}{|l|l|c|c|c|c|}
\hline \multicolumn{2}{|c|}{} & Frequency & Percent & $\begin{array}{c}\text { Valid } \\
\text { Percent }\end{array}$ & $\begin{array}{c}\text { Cumulative } \\
\text { Percent }\end{array}$ \\
\hline \multirow{4}{*}{ Valid } & $18-25$ THN & 19 & 34.5 & 34.5 & 34.5 \\
\cline { 2 - 6 } & $26-35$ THN & 27 & 49.1 & 49.1 & 83.6 \\
\cline { 2 - 6 } & $36-45$ THN & 9 & 16.4 & 16.4 & 100.0 \\
\cline { 2 - 6 } & Total & 55 & 100.0 & 100.0 & \\
\hline
\end{tabular}

Sumber: Hasil pengolahan data SPSS V.25, 2018

Berdasarkan Tabel 4.2 dapat digambarkan bahwa jumlah responden sebanyak 55, dengan jumlah responden dengan usia 18-25 tahun sebanyak 19 orang, responden dengan usia 26-35 tahun sebanyak 27 orang, dan responden dengan usia 36-45 tahun sebanyak 9 orang atau sebesar 34.5\% usia antara 18-25 tahun, 49.1\% usia antara 26-35 tahun dan 16.4\% usia antara 36-45 tahun. Hal ini dapat disimpulkan responden dengan usia 26-35 tahun lebih banyak.

\section{Responden Menurut Masa Kerja}

Depenelitian responden berdasarkan klasifikasi masa kerja dalam penelitian ini dapat dilihat pada tabel 5 sebagai berikut:

Tabel 5

Data Responden Berdasarkan Masa Kerja

\begin{tabular}{|l|l|c|c|c|c|}
\hline \multicolumn{2}{|c|}{} & Frequency & Percent & Valid Percent & $\begin{array}{c}\text { Cumulative } \\
\text { Percent }\end{array}$ \\
\hline Valid & $1-3$ THN & 25 & 45.5 & 45.5 & 45.5 \\
\cline { 2 - 6 } & $4-7$ THN & 19 & 34.5 & 34.5 & 80.0 \\
\cline { 2 - 6 } & $\begin{array}{l}8-11 \\
\text { THN }\end{array}$ & 11 & 20.0 & 20.0 & 100.0 \\
\cline { 2 - 6 } & Total & 55 & 100.0 & 100.0 & \\
\hline
\end{tabular}

Sumber: Hasil pengolahan data SPSS V.25, 2018 
Berdasarkan Tabel 4.3 dapat digambarkan bahwa jumlah responden sebanyak 55, dengan jumlah responden dengan masa kerja 1-3 tahun sebanyak 25 orang, responden dengan masa kerja 4-7 tahun sebanyak 19 orang, dan responden dengan masa kerja 8-11 tahun sebanyak 11 orang atau sebesar 45.5\% masa kerja antara 1-3 tahun, 34.5\% masa kerja antara 4-7 tahun dan 20.0\% masa kerja antara 8-11 tahun. Hal ini dapat disimpulkan responden dengan masa kerja 1-3 tahun lebih banyak.

\section{Responden Menurut Pendidikan Terakhir}

Depenelitian responden berdasarkan klasifikasi masa kerja dalam penelitian ini dapat dilihat pada tabel 6 sebagai berikut:

Tabel 6

Data Responden Berdasarkan Pendidikan Terakhir

\begin{tabular}{|c|c|c|c|c|c|}
\hline \multicolumn{6}{|c|}{ Pendidikan Terakhir } \\
\hline & & Frequency & Percent & Valid Percent & $\begin{array}{c}\text { Cumulative } \\
\text { Percent }\end{array}$ \\
\hline \multirow[t]{4}{*}{ Valid } & SMA/SMK & 40 & 72.7 & 72.7 & 72.7 \\
\hline & D3 & 8 & 14.5 & 14.5 & 87.3 \\
\hline & $\mathrm{S} 1$ & 7 & 12.7 & 12.7 & 100.0 \\
\hline & Total & 55 & 100.0 & 100.0 & \\
\hline
\end{tabular}

Sumber: Hasil pengolahan data SPSS V.25, 2018

Berdasarkan Tabel 6 dapat digambarkan bahwa jumlah responden sebanyak 55, dengan jumlah responden dengan pendidikan terakhir SMA/SMK sebanyak 40 orang, responden dengan pendidikan terakhir D3 sebanyak 8 orang dan ressponden dengan pendidikan terakhir S1 sebanyak 7 orang atau sebesar $72.7 \%$ dengan pendidikan terakhir SMA/SMK, $14.5 \%$ dengan pendidikan terakhir D3, dan $12.7 \%$ dengan pendidikan terakhir S1. Oleh karena itu dapat disimpulkan responden dengan pendidikan terakhir SMA/SMK lebih banyak daripada dengan pendidikan terakhir D3 dan S1.

\section{Hasil Penelitian}

Langkah paling penting dalam mengumpulkan data adalah melakukan pengujian terhadap instrumen (alat ukur) yang akan digunakan kegiatan pengujian instrumen penelitian ini meliputi dua hal yaitu pengujian validitas dan reliabilitas. 


\section{Uji Validitas}

Uji validitas ini digunakan untuk mengetahui apakah instrument (kuesioner) yang dipersiapkan. Tujuannya untuk mengukur ketepatan kuesioner alat ukur dapat mengukur kejadian yang diukur butir-butir pernyataan dinyatakan valid apabila:

a. Jika $r$ hitung > $r$ tabel, maka pernyataan itu valid.

b. Jika $\mathrm{r}$ hitung < r tabel, maka pernyataan itu tidak valid.

Dengan menggunakan olahan SPSS V.25 dimana $\mathrm{r}$ hitung lebih besar dari $\mathrm{r}$ tabel, dengan sampel 55 dan $\mathrm{r}$ tabel 0,266. Hasil pengujian validitas dilakukan. Berikut hasil uji validitas untuk masing - masing variabel:

Tabel 7

Uji Validitas

\begin{tabular}{|c|c|c|c|c|}
\hline Variabel & Item & r Hitung & r Tabel & Keterangan \\
\hline \multirow{7}{*}{$\begin{array}{c}\text { Gaya } \\
\text { Kepemimpinan } \\
\text { (X1) }\end{array}$} & $\mathrm{X} 1.1$ & 0,544 & 0,266 & Valid \\
\hline & $\mathrm{X} 1.2$ & 0,624 & 0,266 & Valid \\
\hline & $\mathrm{X} 1.3$ & 0,803 & 0,266 & Valid \\
\hline & $\mathrm{X} 1.4$ & 0,666 & 0,266 & Valid \\
\hline & $X 1.5$ & 0,803 & 0,266 & Valid \\
\hline & X1. 6 & 0,356 & 0,266 & Valid \\
\hline & $\mathrm{X} 1.7$ & 0,699 & 0,266 & Valid \\
\hline \multirow{6}{*}{$\begin{array}{c}\text { Beban Kerja } \\
\text { (X2) }\end{array}$} & $\mathrm{X} 2.1$ & 0,779 & 0,266 & Valid \\
\hline & $\mathrm{X} 2.2$ & 0,739 & 0,266 & Valid \\
\hline & $\mathrm{X} 2.3$ & 0,718 & 0,266 & Valid \\
\hline & $\mathrm{X} 2.4$ & 0,688 & 0,266 & Valid \\
\hline & $\mathrm{X} 2.5$ & 0,296 & 0,266 & Valid \\
\hline & X2. 6 & 0,502 & 0,266 & Valid \\
\hline \multirow{5}{*}{$\begin{array}{c}\text { Job } \\
\text { Insecurity } \\
\text { (X3) }\end{array}$} & X3. 1 & 0,478 & 0,266 & Valid \\
\hline & $\mathrm{X} 3.2$ & 0,808 & 0,266 & Valid \\
\hline & X3. 3 & 0,382 & 0,266 & Valid \\
\hline & $\mathrm{X} 3.4$ & 0,605 & 0,266 & Valid \\
\hline & $\mathrm{X} 3.5$ & 0,838 & 0,266 & Valid \\
\hline \multirow{2}{*}{$\begin{array}{l}\text { Turnover } \\
\text { Intention }\end{array}$} & Y. 1 & 0,463 & 0,266 & Valid \\
\hline & Y. 2 & 0,725 & 0,266 & Valid \\
\hline$(\mathrm{Y})$ & Y. 3 & 0,813 & 0,266 & Valid \\
\hline
\end{tabular}




\begin{tabular}{|c|c|c|c|c|}
\hline \multirow{4}{*}{ Y.4 } & 0,403 & 0,266 & Valid \\
\cline { 2 - 5 } & Y.5 & 0,370 & 0,266 & Valid \\
\cline { 2 - 5 } & Y.6 & 0,814 & 0,266 & Valid \\
\hline
\end{tabular}

Sumber: Hasil pengolahan data SPSS V.25, 2018

Hasil uji validitas seperti ditampilkan pada Tabel 4.5 menunjukkan bahwa semua butir pernyataan mempunyai nilai $\mathrm{r}$ hitung $>\mathrm{r}$ tabel, dengan taraf signifikan $\alpha=0,05$ dan nilai $\mathrm{r}$ tabel nya sebesar 0,266 dapat disimpulkan bahwa semua pernyataan pada variabel X1, X2, X3, dan Y dinyatakan valid.

\section{Uji Reliabilitas}

Uji Reliabilitas dilakukan untuk mendapatkan tingkat ketepatan alat pengumpulan data yang digunakan. Pengukuran reliabilitas dilakukan dengan menggunakan SPSS V.25 uji statistik Cronbrach's Alpha. Berikut hasil uji reliabilitas untuk masing - masing variable.

\section{Tabel 8}

\section{Hasil Uji Reliabilitas}

\begin{tabular}{|c|l|c|c|c|}
\hline No & \multicolumn{1}{|c|}{ Variabel } & $\begin{array}{c}\text { Cronbach's } \\
\text { Alpha }\end{array}$ & $\begin{array}{c}\text { Cronbach's } \\
\text { Alpha yang } \\
\text { disyaratkan }\end{array}$ & Keterangan \\
\hline 1. & $\begin{array}{l}\text { Gaya Kepemimpinan } \\
\text { (X1) }\end{array}$ & 0,762 & 0,60 & Reliabel \\
\hline 2. & Beban Kerjaaa (X2) & 0,666 & 0,60 & Reliabel \\
\hline 3. & Job Insecurity (X3) & 0,607 & 0,60 & Reliabel \\
\hline 4. & $\begin{array}{l}\text { Turnover Intention } \\
\text { (Y) }\end{array}$ & 0,672 & 0,60 & Reliabel \\
\hline
\end{tabular}

Sumber : Hasil pengolahan data SPSS V.25, 2018

Pada Tabel 8 diatas dapat dilihat bahwa R Alpha dari masing - masing variabel X1, X2, X3 dan Y lebih besar dari 0,60. Dengan demikian dapat disimpulkan bahwa data yang diuji tersebut dinyatakan reliabel.

\section{Uji Asumsi Klasik}

\section{Uji Normalitas}

Uji normalitas dilakukan guna mengetahui nilai residu (perbedaan yang ada) yang diteliti memiliki distribusi normal sebagai salah satu syarat analisis data dengan statistik parametris yang digunakan dalam penelitian ini. Uji normalitas dilakukan secara visual dengan 
histogram dan Normal Probabiliy plot Regresion Standarized rResidual, serta melalui uji Kolmogorov-Smirnov. Hasil pengujian disajikan sebagai berikut:

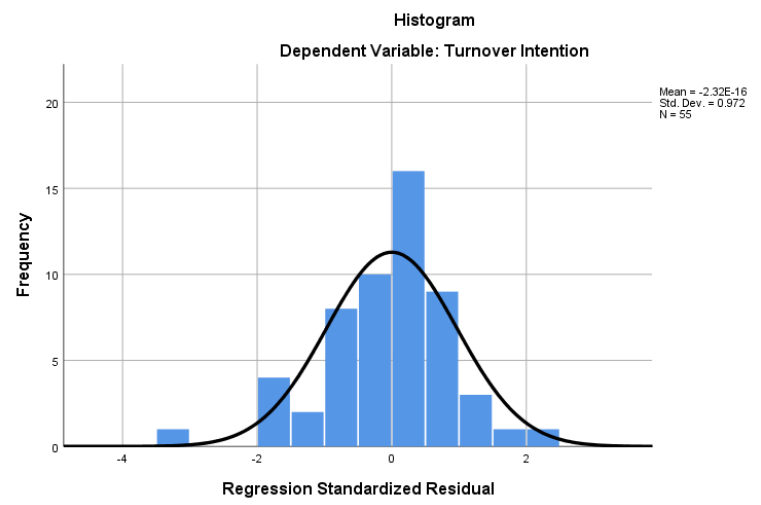

Gambar 1 Hasil Uji Histogram

Sumber : Hasil pengolahan data SPSS V.25, 2018

Gambar 1 memperhatikan dan membentuk pola gambar lonceng atau bell shaped, maka dapat disimpulkan bahwa data memiliki distribusi normal. Cara kedua untuk menguji normalitas adalah dengan melihat gambar grafik Normal Probability plot of Regresion Standarized Residual dibawah ini:

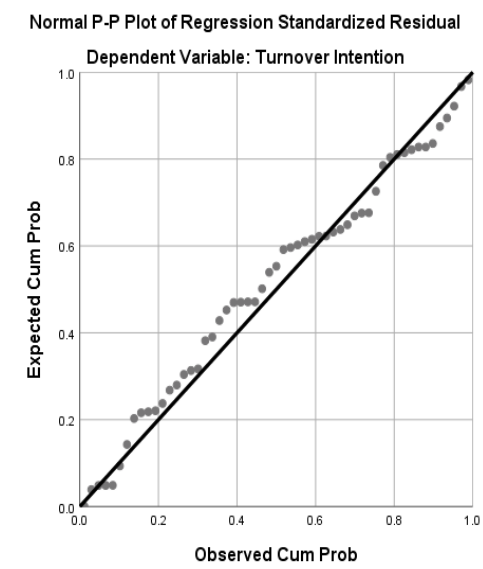

\section{Gambar 2 Hasil Uji Grafik Normal Probability Plot}

Sumber : Hasil pengolahan data SPSS V.25, 2018 
Gambar 2 memperlihatkan ketentuan bahwa titik-titik data menyebar disekitar garis diagonal dan mengikuti arah garis diagonal maka dapat dikatakan data memenuhi asumsi normalitas. Pengujian ini diperkuat dengan hasil uji Kolmogorov Smirnov yang tampak pada Tabel 9

\section{Tabel 9}

One-Sample Kolmogorov-Smirnov Test

\begin{tabular}{|l|l|r|}
\hline \multicolumn{2}{|c|}{ One-Sample Kolmogorov-Smirnov Test } \\
\hline \multicolumn{2}{|c|}{} & \multicolumn{1}{|c|}{ Unstandardized Residual } \\
\hline $\mathrm{N}$ & Mean & 55 \\
\cline { 2 - 3 } Normal Parameters & St, & .0000000 \\
\cline { 2 - 4 } & Std. Deviation & .04341089 \\
\hline Most Extreme Differences & Absolute & .087 \\
\cline { 2 - 3 } & Positive & .066 \\
\cline { 2 - 3 } & Negative & .087 \\
\hline Test Statistic & & .087 \\
\hline Asymp. Sig. (2-tailed) & & $.200^{\mathrm{c}, \mathrm{d}}$ \\
\hline
\end{tabular}

a. Test distribution is Normal.

b. Calculated from data.

c. Lilliefors Significance Correction.

d. This is a lower bound of the true significance.

Sumber : Hasil pengolahan data SPSS V.25, 2018

Berdasarkan hasil uji Kolmogorov-smirnov pada Tabel 9 diatas diketahui nilai Asymp. Sig. (2-tailed) $0.200>0,05$ (alpha), maka dapat disimpulkan bahwa nilai residual berdistribusi normal.

\section{Uji Multikolinearitas}

Uji multikolinearitas bertujuan untuk menguji apakah model regresi ditemukan adanya korelasi antar variabel bebas (independen). Uji multikolinearitas dalam penelitian ini dengan melihat Variance Inflation Factor (VIF) dan Tolerance pada model regresi. Jika nilai VIF kurang dari 10 dan Tolerance lebih dari 0,1 maka model regresi bebas dari multikolinearitas. Artinya tidak terdapat hubungan antara variabel bebas. Hasil pengujian multikolinearitas dengan nilai VIF adalah sebagai berikut: 
Tabel 10

Hasil Uji Multikolinearitas

\begin{tabular}{|c|c|c|c|}
\hline \multicolumn{4}{|c|}{ Coefficients $^{\mathrm{a}}$} \\
\hline \multirow{2}{*}{\multicolumn{2}{|c|}{ Model }} & \multicolumn{2}{|c|}{ Collinearity Statistics } \\
\hline & & Tolerance & VIF \\
\hline \multirow[t]{4}{*}{1} & (Constant) & & \\
\hline & Gaya Kepemimpinan & 0.936 & 1.069 \\
\hline & Beban Kerja & 0.962 & 1.039 \\
\hline & Job Insecurity & 0.951 & 1.051 \\
\hline
\end{tabular}

a. Dependent Variable: Turnover Intention

Sumber : Hasil pengolahan data SPSS V.25, 2018

Tabel 10 menunjukkan bahwa nilai VIF untuk variabel X1, X2, dan X3 masing-masing sebesar 1,069; 1,039; dan 1,051 sehingga dapat disimpulkan bahwa dalam model regresi tidak terdapat gejala multikolinearitas antar variabel bebas karena nilai VIF lebih kecil dari 10 yang berarti bahwa semua variabel tersebut dapat digunakan sebagai variabel yang saling independen.

\section{Uji Heteroskedastisitas}

Uji heteroskedastisitas digunakan untuk mengetahui ada atau tidaknya penyimpangan asumsi klasik heteroskedastisitas yaitu adanya ketidaksamaan varian dari residual untuk semua pengamatan pada model regresi. Penelitian ini menggunakan metode Glejser dan Scatterplot untuk menguji gejala heteroskedastisitasnya dengan hasil sebagai berikut:

Tabel 11

\section{Hasil Uji Heteroskedastisitas}

\begin{tabular}{|c|c|c|c|c|c|c|}
\hline \multicolumn{7}{|c|}{ Coefficients $^{\mathrm{a}}$} \\
\hline & & \multicolumn{2}{|c|}{$\begin{array}{c}\text { Unstandardized } \\
\text { Coefficients }\end{array}$} & \begin{tabular}{|c} 
Standardized \\
Coefficients
\end{tabular} & \multirow[b]{2}{*}{$\mathrm{t}$} & \multirow[b]{2}{*}{ Sig. } \\
\hline \multicolumn{2}{|c|}{ Model } & $\mathrm{B}$ & Std. Error & Beta & & \\
\hline \multirow[t]{4}{*}{1} & (Constant) & 4.975 & 2.325 & & 2.140 & .037 \\
\hline & $\begin{array}{l}\text { Gaya } \\
\text { Kepemimpinan }\end{array}$ & -.078 & .057 & -.190 & -1.376 & .175 \\
\hline & Beban Kerja & -.108 & .074 & -.200 & -1.470 & .148 \\
\hline & Job Insecurity & .098 & .086 & .156 & 1.138 & .260 \\
\hline
\end{tabular}

a. Dependent Variable: RES2

Sumber: Hasil pengolahan data SPSS V.25, 2018 
Hasil pengujian Glejser melihat nilai probabilitas dengan signifikansi > nilai alpha $(0,05)$ maka model tidak mengalami heteroskedastisitas. Pada Tabel 11 diketahui bahwa nilai probabilitas atau signifikansi dari masing-masing variabel 0,175; 0,148; dan 0,260 lebih besar dari nilai alpha $(0,05)$ maka dapat disimpulkan bahwa dalam model regresi tidak terdapat gejala heteroskedastisitas.

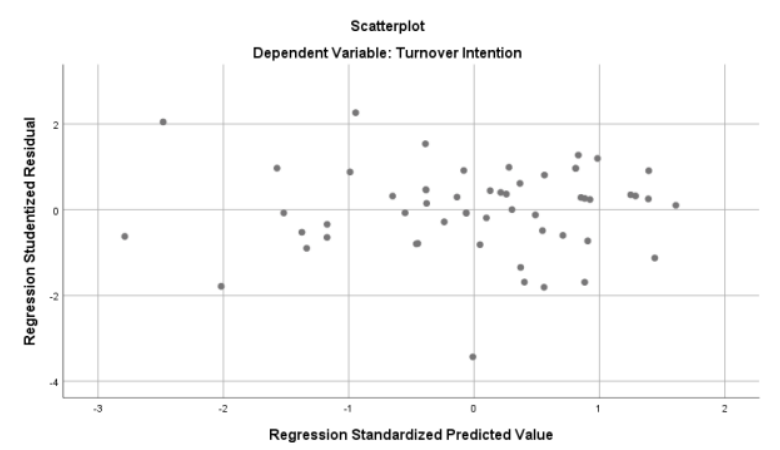

\section{Gambar 3 Hasil Uji Heteroskedastisitas dalam Scatterplot}

Sumber : Hasil pengolahan data SPSS V.25, 2018

Berdasarkan Gambar 3 dapat dilihat persebaran titik-titik yang acak di atas maupun di bawah angka 0 dari sumbu Y. Dapat disimpulkan dari gambar tersebut bahwa dalam model regresi tidak terjadi heterooskedastitas.

\section{Uji Hipotesis}

\section{Analisa Uji Regresi Linier Berganda}

Regresi linear berganda digunakan untuk meramalkan pengaruh variabel-variabel bebas terhadap variabel terikat untuk membuktikan ada atau tidaknya hubungan fungsional antara variabel-variabel tersebut. Persamaan regresi dapat diketahui pada output SPSS pada Tabel 12. 


\section{Tabel 12}

Hasil Uji Regresi Linear Berganda

\begin{tabular}{|c|c|c|c|c|c|c|}
\hline \multicolumn{7}{|c|}{ Coefficients $^{\mathrm{a}}$} \\
\hline \multirow{2}{*}{\multicolumn{2}{|c|}{ Model }} & \multicolumn{2}{|c|}{$\begin{array}{c}\text { Unstandardized } \\
\text { Coefficients }\end{array}$} & \multirow{2}{*}{$\begin{array}{c}\begin{array}{c}\text { Standardized } \\
\text { Coefficients }\end{array} \\
\text { Beta } \\
\end{array}$} & \multirow[b]{2}{*}{$\mathrm{T}$} & \multirow[b]{2}{*}{ Sig. } \\
\hline & & $\mathrm{B}$ & Std. Error & & & \\
\hline \multirow[t]{4}{*}{1} & (Constant) & 3.483 & 3.766 & & .925 & .359 \\
\hline & $\begin{array}{l}\text { Gaya } \\
\text { Kepemimpinan }\end{array}$ & .099 & .092 & .129 & 1.079 & .286 \\
\hline & Beban Kerja & .348 & .119 & .344 & 2.912 & .005 \\
\hline & Job Insecurity & .404 & .139 & .345 & 2.900 & .005 \\
\hline
\end{tabular}

a. Dependent Variable: Turnover Intention

Sumber: Hasil pengolahan data SPSS V.25, 2018

Berdasarkan Tabel 12 dapat diperoleh persamaan regresi linear berganda sebagai berikut: $\mathrm{Y}=3,483+0,099 \mathrm{X} 1+0,348 \mathrm{X} 2+0,404 \mathrm{X} 3+\mathrm{e}$

\section{Analisis Uji T (Parsial)}

Uji t digunakan untuk mengukur apakah dalam model regresi variabel bebas secara parsial berpengaruh secara signifikan terhadap variabel terikat. Pengujian dilakukan dengan menggunakan $\mathrm{t}$ hitung dan tingkat signifikan. Uji $\mathrm{T}$ digunakan untuk mengetahui apakah secara parsial variabel $\mathrm{X}$ berpengaruh signifikan terhadap variabel $\mathrm{Y}$. Dimana untuk mengetahui nilai t tabel dapat menggunakan rumus $\mathrm{df}=\mathrm{n}-\mathrm{k}-1 \mathrm{di}$ mana df adalah nilai uji $\mathrm{t}$, $\mathrm{n}$ adalah jumlah responden, $\mathrm{k}$ adalah jumlah variabel bebas, dan 1 adalah nilai ketetapan dari rumus. Berarti untuk mengetahui nilai t tabel pada uji $\mathrm{t}$ dalam penelitian ini $\mathrm{df}=55-3-1=$ 51, $\mathrm{t}$ tabel dari angka 51 adalah 2,007. Kriteria penguji Ho di terima jika $t_{\text {tabel }} \leq \mathrm{t}_{\text {hitung }}$ dan Ho di tolak jika $\mathrm{t}_{\text {hitung }}<\mathrm{t}_{\text {tabel }}$ atau $\mathrm{t}_{\text {hitung }}>\mathrm{t}_{\text {tabel }}$ dan besarnya pengaruhi masing - masing variabel independen terhadap variabel dependen dengan melihat nilai beta. 
Tabel 13

Hasil Uji T (Parsial)

\begin{tabular}{|c|c|c|c|c|c|c|}
\hline \multicolumn{7}{|c|}{ Coefficients $^{\mathrm{a}}$} \\
\hline \multirow{2}{*}{\multicolumn{2}{|c|}{ Model }} & \multicolumn{2}{|c|}{$\begin{array}{c}\text { Unstandardized } \\
\text { Coefficients }\end{array}$} & \multirow{2}{*}{$\begin{array}{c}\begin{array}{c}\text { Standardized } \\
\text { Coefficients }\end{array} \\
\text { Beta } \\
\end{array}$} & \multirow[b]{2}{*}{$\mathrm{T}$} & \multirow[b]{2}{*}{ Sig. } \\
\hline & & $\mathrm{B}$ & Std. Error & & & \\
\hline \multirow[t]{4}{*}{1} & (Constant) & 3.483 & 3.766 & & .925 & .359 \\
\hline & $\begin{array}{l}\text { Gaya } \\
\text { Kepemimpinan }\end{array}$ & .099 & .092 & .129 & 1.079 & .286 \\
\hline & Beban Kerja & .348 & .119 & .344 & 2.912 & .005 \\
\hline & Job Insecurity & .404 & .139 & .345 & 2.900 & .005 \\
\hline
\end{tabular}

a. Dependent Variable: Turnover Intention

Sumber: Hasil pengolahan data SPSS V.25, 2018

Hasil dari Tabel 13 menunjukkan bahwa variabel Gaya Kepemimpinan (X1) nilai t hitung 1,079 < t tabel 2,007 dan nilai signifikan 0,286 > 0,05 sehingga keputusan yang diambil adalah $\mathrm{H}_{\mathrm{o}}$ diterima dan $\mathrm{H}_{\mathrm{a}}$ ditolak. Hal ini berarti Gaya Kepemimpinan berpengaruh tidak signifikan terhadap Turnover Intention.

Variabel Beban Kerja (X2) menunjukkan nilai t hitung 2,912 > t tabel 2,007 dan nilai signifikan 0,005 $<0,05$ sehingga keputusan yang diambil adalah $\mathrm{H}_{\mathrm{o}}$ ditolak dan $\mathrm{H}_{\mathrm{a}}$ diterima. Hal ini berarti bahwa Beban Kerja berpengaruh secara signifikan terhadap Turnover Intention.

Variabel Job Insecurity (X3) nilai t hitung 2,900 > t tabel 2,007 dan nilai signifikan $0,005<0,05$ sehingga keputusan yang diambil adalah $\mathrm{H}_{\mathrm{o}}$ ditolak dan $\mathrm{H}_{\mathrm{a}}$ diterima. Hal ini berarti bahwa Job Insecurity berpengaruh secara signifikan terhadap Turnover Intention.

\section{Analisi Uji F (Simultan)}

Uji F digunakan untuk mengetahui apakah seluruh variabel independen secara bersama-sama mempunyai pengaruh yang positif terhadap variabel dependen. Uji Simultan atau Uji F merupakan pengujian yang dilakukan pada keseluruhan variabel independen (bebas) dengan tujuan untuk menentukan apakah variabel tersebut secara serentak atau bersama-sama mempunyai pengaruh yang signifikan terhadap variabel dependen (terikat). Tingkat signifikan pada uji $\mathrm{F}$ adalah sebesar 0,05 (5\%). Kriteria yang digunakan adalah apabila nilai signifikan > 
0,05 maka Ho diterima sedangkan sebaliknya jika nilai signifikan < 0,05 maka Ho ditolak. Hasil uji simultan F pada Tabel 14 berikut ini:

\section{Tabel 14}

Hasil Uji F

ANOVA $^{a}$

\begin{tabular}{|l|l|c|c|c|c|c|}
\hline \multicolumn{2}{|l|}{ Model } & Sum of Squares & Df & Mean Square & F & Sig. \\
\hline \multirow{4}{*}{1} & Regression & 230.560 & 3 & 76.853 & 7.836 & $.000^{\mathrm{b}}$ \\
\cline { 2 - 7 } & Residual & 500.167 & 51 & 9.807 & & \\
\cline { 2 - 7 } & Total & 730.727 & 54 & & & \\
\hline
\end{tabular}

a. Dependent Variable: Turnover Intention

b. Predictors: (Constant), Job Insecurity, Beban Kerja, Gaya Kepemimpinan Sumber : Hasil pengolahan data SPSS V.25, 2018

Hasil uji F memperlihatkan nilai F sebesar 7,836 (F hitung) > 2,78 (F tabel) dan nilai signifikansi sebesar 0,000 $<0,05$ sehingga keputusan yang diambil adalah $\mathrm{H}_{\mathrm{o}}$ ditolak dan $\mathrm{H}_{\mathrm{a}}$ diterima. Hasil ini menunjukkan bahwa variabel Gaya Kepemimpinan (X1), Beban Kerja (X2), dan Job Insecurity (X3) secara simultan berpengaruh signifikan terhadap variabel Turnover Intention (Y).

\section{Uji Koefisien Determinasi $\left(\mathbf{R}^{2}\right)$}

Koefisien determinasi $\left(\mathrm{R}^{2}\right)$ berfungsi menjelaskan proporsi variasi dalam variabel terikat (Y) yang dijelaskan oleh variabel bebas (lebih dari satu variabel) secara bersama-sama. Nilai koefisien determinasi adalah antara nol dan satu. Hasil pengujian koefisien determinasi dalam penelitian ini adalah:

\section{Tabel 15}

\section{Model Summary}

\begin{tabular}{|l|c|r|r|r|}
\hline Model & $\mathrm{R}$ & R Square & $\begin{array}{c}\text { Adjusted } R \\
\text { Square }\end{array}$ & Std. Error of the Estimate \\
\hline 1 & $.562^{\mathrm{a}}$ & .316 & .275 & 3.13164 \\
\hline \multicolumn{2}{|l|}{ a. Predictors: (Constant), Job Insecurity, Beban Kerja, Gaya Kepemimpinan } \\
\hline
\end{tabular}

Sumber : Hasil pengolahan data SPSS V.25, 2018

Tabel 15 memperlihatkan nilai R Square sebesar 0,316, hal ini mengandung arti bahwa pengaruh Gaya Kepemimpinan, Beban Kerja, Job insecurity secara simultan terhadap 
Turnover Intention adalah sebesar 31.6\%. sedangkan sisanya yaitu 68,4\% dipengaruhi oleh variabel lainya yang tidak diteliti.

\section{Pengaruh Gaya Kepemimpinan Terhadap Turnover Intention}

Berdasarkan hasil pengujian dapat dilihat Gaya Kepemimpinan (X1) dengan nilai signifikan sebesar 0,286 > 0,05 (nilai alpha) hal ini menunjukkan bahwa Gaya Kepemimpinan (X1) berpengaruh tidak signifikan terhadap Turnover Intention (Y). Hal ini diperkuat dengan hasil nilai t hitung 1,079 < t tabel 2,007 menunjukkan bahwa variabel Gaya Kepemimpinan (X1) berpengaruh tidak signifikan terhadap Turnover Intention.

Berdasarkan hal tersebut, maka variabel Gaya Kepemimpinan memiliki peran tidak penting dalam mempengaruhi Turnover Intention pada PT. FIF GROUP Cabang Batam. Hasil penelitian ini mendukung hasil penelitian Agung Utomo (2017) dengan hasil penelitian Gaya kepemimpinan transformasional berpengaruh negatif terhadap turnover intention karyawan PT. Veronique Indonesia. Oktaviani (2016) dengan hasil penelitian hasil dari pengujian hipotesis $\mathrm{H} 2$ menunjukkan bahwa tidak terdapat pengaruh antara gaya kepemimpinan terhadap intensi turnover karyawan di UD Indigo Sejahtera. Fitryani D.A (2018) dengan hasil penelitian Kepemimpinan, komitmen organisasi dan kepuasan kerja secara simultan dan parsial karyawan berpengaruh negatif dan signifikan terhadap turnover intention karyawan

\section{Pengaruh Beban Kerja Terhadap Turnover Intention}

Berdasarkan hasil pengujian dapat dilihat bahwa Komitmen Organisasi (X2) dengan nilai signifikan sebesar 0,005 0,05 (nilai alpha) menunjukkan adanya hubungan signifikan antara Beban Kerja (X2) dengan Turnover Intention (Y). Hal ini diperkuat dengan hasil nilai t hitung 2,912 > t tabel 2,007 menunjukkan bahwa variabel Beban Kerja (X2) berpengaruh signifikan terhadap Turnover Intention.

Berdasarkan hal tersebut, maka variabel Beban Kerja memiliki peran penting dalam mempengaruhi Turnover Intention pada PT. FIF GROUP Cabang Batam. Hasil penelitian ini mendukung hasil penelitian. M. Irfan Thamrin (2018) dengan hasil penelitian terdapat pengaruh yang signifikan antara beban kerja dengan turnover intention di hotel grand rocky bukittinggi. Hanifah Nur'Aini (2018) dengan hasil penelitian terdapat pengaruh beban kerja berpengaruh positif dan signifikan terhadap turnover intention medical representative di 
wilayah Yogyakarta. Turmuzi, M (2017) dengan hasil Penelitian beban kerja berpengaruh positif signifikan terhadap turnover intention karyawan. Laksmi Sito Dwi Irvianti (2014) dengan hasil penelitian beban kerja secara parsial berpengaruh terhadap variabel turnover intention. Rosyad A (2017) dengan hasil penelitian beban kerja berpengaruh positif terhadap turnover intention.

\section{Pengaruh Job Insecurity Terhadap Turnover Intention}

Berdasarkan hasil pengujian dapat dilihat bahwa Job Insecurity (X3) dengan nilai signifikan sebesar nilai signifikan 0,005 < 0,05 (nilai alpha) menunjukkan adanya hubungan yang signifikan antara Job Insecurity (X3) dengan Turnover Intention (Y). Hal ini diperkuat dengan hasil t hitung 2,900 > t tabel 2,007 menunjukkan bahwa variabel Job Insecurity (X3) berpengaruh signifikan terhadap Turnover Intention.

Berdasarkan hal tersebut, maka variabel Job Insecurity memiliki peran penting dalam mempengaruhi Turnover Intention pada PT. FIF GROUP Cabang Batam. Hasil penelitian ini mendukung hasil penelitian. Sandi (2014) dengan hasil penelitian Job insecurity berpengaruh positif dan signifkan terhadap Turnover intention. Halimah, dkk (2016) dengan hasil penelitian menunjukkan ada pengaruh positif antara variable job insecurity terhadap turnover karyawan. Septiari (2016) dengan hasil penelitian Job insecurity berpengaruh positif dan signifikan terhadap turnover intention karyawan. Puput (2015) dengan Hasil Penelitian Ada pengaruh job insecurity positif dan signifikan terhadap turnover intention Sopir P.O CWM Jember. Wicaksono (2013) dengan hasil penelitian Job Insecurity berpengaruh positif dan signifikan terhadap Turnover Intention, sehingga hipotesis satu di terima

\section{Pengaruh Gaya kepemimpinan, Beban Kerja, dan Job Insecurity Terhadap Turnover Intention}

Hasil uji F menunjukkan bahwa nilai signifikan dari 3 variabel bebas yaitu variabel Beban Kerja (X1), Komitmen Organisasi (X2), dan Job Insecurity (X3) sebesar 0,000 dan F hitung 7,836. Hasil ini memperlihatkan bahwa variabel Gaya Kepemimpinan (X1), Beban Kerja (X2), dan Job Insecurity (X3) secara bersama-sama memiliki pengaruh yang signifikan terhadap Turnover Intention (Y). 
Hasil perhitungan regresi dapat diketahui bahwa koefisien determinasi ( $R$ Square) yang diperoleh sebesar 0,316. Hal ini berarti 31,6 \% Gaya Kepemimpinan (X1), Beban Kerja (X2), dan Job Insecurity (X3) sedangkan sisanya yaitu 68,4\% Turnover Intention dipengaruhi oleh variabel-variabel lain yang tidak dijelaskan dalam penelitian ini.

\section{KESIMPULAN}

Berdasarkan hasil penelitian dan pembahasan yang telah dilakukan pada bab sebelumnya, maka dapat disimpulkan bahwa:

1. Pengujian hipotesis untuk variabel Gaya Kepemimpinan (X1) menunjukan hasil t hitung $1,079<\mathrm{t}$ tabel 2,007 dan signifikan sebesar 0,286>0,05 sehingga keputusan yang diambil adalah $\mathrm{H}_{\mathrm{o}}$ diterima dan $\mathrm{H}_{\mathrm{a}}$ ditolak. Hal ini berarti Gaya Kepemimpinan berpengaruh tidak signifikan terhadap Turnover Intention.

2. Pengujian hipotesis untuk variabel Beban Kerja (X2) menunjukkan nilai t hitung 2,912 $>\mathrm{t}$ tabel 2,007 dan nilai signifikan 0,005 < 0,05 sehingga keputusan yang diambil adalah $\mathrm{H}_{\mathrm{o}}$ ditolak dan $\mathrm{H}_{\mathrm{a}}$ diterima. Hal ini berarti bahwa Beban Kerja berpengaruh secara signifikan terhadap Turnover Intention.

3. Pengujian hipotesis variabel Job Insecurity (X3) nilai t hitung 2,900 > t tabel 2,007 dan nilai signifikan $0,005<0,05$ sehingga keputusan yang diambil adalah $\mathrm{H}_{\mathrm{o}}$ ditolak dan $\mathrm{H}_{\mathrm{a}}$ diterima. Hal ini berarti bahwa Job Insecurity berpengaruh secara signifikan terhadap Turnover Intention.

4. Hasil uji F memperlihatkan nilai F sebesar 7,836 (F hitung) > 2,78 (F tabel) dan nilai signifikansi sebesar $0,000<0,05$ sehingga keputusan yang diambil adalah $\mathrm{H}_{\mathrm{o}}$ ditolak dan $\mathrm{H}_{\mathrm{a}}$ diterima. Hasil ini menunjukkan bahwa variabel Gaya Kepemimpinan (X1), Beban Kerja (X2), dan Job Insecurity (X3) secara simultan pengaruh signifikan terhadap variabel Turnover Intention (Y).

\section{Saran}

Berdasarkan hasil penelitian ini, beberapa saran atau rekomendasi yang dapat diberikan kepada perusahaan maupun untuk penelitian yang akan datang sebagai berikut:

1. PT. FIF diharapkan mengatur kembali beban kerja agar tidak menjadi beban berat bagi karyawan sehingga karyawan merasa nyaman dan tidak pindah,. 
2. PT. FIF diharapkan memperhatikan Job Insecurity agar karyawan nyaman dan tidak keluar.

3. PT. FIF diharapkan mengurangi beban kerja dan memperhatikan Job Insecurity agar karyawan nyaman dan tidak pindah

\section{DAFTAR PUSTAKA}

Ghozali, I. (2013). Aplikasi Analisis Multivariate dengan Program IBM SPSS. Semarang: Universitas Diponogoro.

Hanafiah, M. (2014). "Pengaruh Kepuasan Kerja dan Ketidakamanan Kerja dengan Intensi Pindah Kerja (Turnover) pada Karyawan PT.Buma Desa Suaran Kecematan Sambilung Kabupaten Berau”. E-Jurnal Psikologi, 1(3), pp:303-312.

Kekesi, Elias Kodjo, \& Collins Badu Agymang. (2014). "Perceived Job Insecurity and Psychological Distres: The Moderating Role of Work Values”. International Journal of Management, Economics and Social Sciences, 3 (1), pp: 18-35.

Suciati, Andi tri Haryono, \& Maria Magnalena Minarsih . (2015). "Pengaruh Job Insecurity dan Stres Kerja Terhadap Turnover Intention Pegawai pada Karyawan PT.Berkat Abadi Surya Cemerlang Semarang (HO)". Jurnal Manajemen Universitas Pandanaran, 1 (1), pp: 1-2.

Sugiyono. (2015). Memahami Penelitian dan Pengembangan. Bandung: Alfabeta.

Sugiyono. (2016). Pendekatan Kuanttitatif, Kualitatif, dan R \& D. Bandung: Alfabeta.

Sugiyono. (2018). Metode Penilitian Manajemen. Bandung: Alfabeta.

Sutikno. (2014). Pemimpin Dan Gaya Kepemimpinan. Edisi Pertama Lombok: Holistica.

Tarwaka. (2015). Ergonomi Industri (Dasar-dasar Pengetahuan Ergonomi dan Aplikasi di Tempat Kerja). Surakarta: Harapan Press.

Waspodo. A.AWS, H. N. (2013). Pengaruh Kepuasan Kerja Dan Stres Kerja Terhadap Turnover Intention Pada Karyawan PT. Unitex Di Bogor. Jurnal Riset Manajemen Sains Indonesia (JRMSI), 4(1), 97-115 